\title{
Mini-Review on Phytochemistry and Pharmacological Studies of Piper regnellii (Miq.) C.DC.
}

\author{
Wan Mohd Nuzul Hakimi Wan Salleh ${ }^{1, *(D)}$, Alene Tawang ${ }^{2}$ (D), Muhammad Haffiz Jauri ${ }^{3}$ (D) \\ 1 Department of Chemistry, Faculty of Science and Mathematics, Universiti Pendidikan Sultan Idris, 35900 Tanjung Malim, \\ Perak, Malaysia; wmnhakimi@fsmt.upsi.edu.my (W.M.N.H.W.S.); \\ 2 Department of Biology, Faculty of Science and Mathematics, Universiti Pendidikan Sultan Idris, 35900 Tanjung Malim, \\ Perak, Malaysia; alene@fsmt.upsi.edu.my (A.T.); \\ 3 Natural Products Division, Forest Research Institute Malaysia, 52109 Kepong, Selangor, Malaysia; haffiz@ frim.gov.my \\ (M.H.J.); \\ * Correspondence: wmnhakimi@ fsmt.upsi.edu.my;
}

Scopus Author ID 56305730900

Received: 08.04.2021; Revised: 12.05.2021; Accepted: 16.05.2021; Published: 10.06.2021

\begin{abstract}
Piper regnellii (Miq.) C.DC. is an herbaceous plant that can be found in tropical and subtropical regions of the world and commonly employed in folk medicine for the treatment of wounds, swellings, and skin irritations. In particular, phytochemical studies on P. regnellii have yielded essential oils, benzofuran neolignans, and phenylpropanoids, while the extracts and compounds demonstrated a broad spectrum of pharmacological activities. The present study aims to provide a review of previously published studies conducted on both the phytochemistry and pharmacological activities of $P$. regnellii. Accordingly, the scientific journals used for this brief literature review were obtained from various electronic sources, including Science Direct, PubMed, Google Scholar, Scopus, and Web of Science. In particular, the outcome of this review is expected to support the therapeutic potential of $P$. regnellii further as well as provide convincing evidence to its future clinical applications in modern medicine. Overall, this is aimed to increase the amount of data that supports the application and exploitation of new drug development.
\end{abstract}

Keywords: Piper regnellii; Piperaceae; phytochemistry; pharmacology; neolignan; essential oil

(C) 2021 by the authors. This article is an open-access article distributed under the terms and conditions of the Creative Commons Attribution (CC BY) license (https://creativecommons.org/licenses/by/4.0/).

\section{Introduction}

Over millions of years, the evolution of natural products has led to their unique chemical diversity, which tends to affect their biological activities and drug-like properties. Moreover, it should be noted that those products have become one of the most important resources in developing new lead compounds and scaffolds [1]. More importantly, natural products will continue to be used in meeting the urgent need of developing effective drugs, which further explains its leading role in the discovery of drugs to treat human diseases, especially critical diseases [2]. In addition, higher plants have served humankind as a source of natural products which act as medicinal agents since the earliest beginnings. In ancient times, a variety of chemical investigations as well as purifications of the extracts of plants with medicinal properties have yielded several purified compounds, which demonstrates its significance in the practice of modern medicine $[3,4]$.

A search of the literature has shown that Piperaceae is one of the plant families which is believed to have high medicinal values due to its wide usage in an abundant amount of traditional medicines [5]. In particular, the Piper species belong to the Piperaceae family, 
which leads it to be considered one of the most ancient flowering plants growing in tropical regions. Furthermore, it should be noted that the genus Piper consists of 700 species that grow in various parts of the world [6]. Essentially, these species are mostly shrubs, climbing herbs, or trees that are extensively distributed in several tropical regions such as Asia, Central and Western Africa, South and Central America, and Pacific Ocean Islands [7]. Apart from that, it is well known as the largest genus in the family with numerous medicinal and traditional uses. In traditional medicine, Piper species have been utilized worldwide to treat several diseases, including urological problems, skin, liver, and stomach ailments, wound healing, and antipyretic and anti-inflammatory agents [8-10]. On a more important note, the chemistry of the Piper species has been widely investigated in a considerable amount of phytochemical studies. Generally, the results of the studies have led to the isolation of numerous biologically active compounds such as alkaloids, lignans, neolignans, terpenes, steroids, kawapyrones, piperolides, flavonoids, followed by the effects of antioxidant, antimicrobial, antiinflammatory, insecticidal, anti-hypertensive, antidiabetics, immunomodulatory, and antimutagenic [11-13].

Piper regnellii (Miq.) C.DC. is an herbaceous plant that grows in tropical and subtropical regions of the world and is popularly known in Brazil as 'pariparoba' or 'caapeba'. In a general sense, its traditional use is for the treatment of wounds, swellings, and skin irritations [14]. In addition, the leaf and root of $P$. regnellii are extensively adopted in the forms of crude extracts, infusions, or plasters in treating wounds and reducing swelling and skin irritations [15]. As previously mentioned, the phytochemical study of the leaves and roots of $P$. regnellii has shown the accumulation of several benzofuran neolignans and phenylpropanoids, which include conocarpan, eupomatenoid-3, eupomatenoid-5, and eupomatenoid-6. Accordingly, they are considered the most significant compounds that can be employed in potential pharmacological studies.

Hence, the current review aims to summarise the available information on the published studies of phytochemistry and pharmacology on $P$. regnellii. The literature used in the current review comprises scientific journals obtained from a variety of electronic sources, namely Science Direct, PubMed, Google Scholar, Scopus, and Web of Science. Accordingly, the present article is believed to provide a better understanding of $P$. regnellii and its properties. More importantly, this data may be valuable in planning future inspections for clinical preliminaries and creating new pharmaceuticals containing $P$. regnellii or its active constituent.

\section{Phytochemistry}

A review of the literature revealed that the phytochemical properties of $P$. regnellii had been extensively investigated since 1999. As a result, a total of eighteen compounds have been isolated from the leaves and roots of $P$. regnellii in which the chemical structures are illustrated in Figure 1. Specifically, the species is reported to contain neolignans [14-21], phenylpropanoids [17], and essential oils [43-51]. Regarding this matter, Macedo et al. [16] have reported the presence of neolignans in various Piper species. For example, the first phytochemical investigation was carried out by Benevides et al. [17] on the species $P$. regnellii, which managed to discover the chemistry of neolignans. In addition, it is important to note the following isolated compounds that were obtained from the roots extracts of $P$. regnellii: neolignans conocarpan (1), eupomatenoid-3 (2), eupomatenoid-5 (3), and eupomatenoid-6 (4), together with $\quad(7 S, 8 R)$-4-hydroxy-4',7-epoxy-8,3'-neolignan-7' $[E]$-ene $\quad(\mathbf{5}), \quad(7 R, 8 R)-3,4-$ methylenedioxy-4',7-epoxy-8,3'-neolignan-7' $[E]$-ene (6), methyl-(7R,8R)-4-hydroxy-8',9'- 
dinor-4',7-epoxy-8,3'-neolignan-7'-ate (7), and (7S,8R)-4-hydroxy-8',9'-dinor-4',7-epoxy-8,3'neolignan-7'-aldehyde (8). Nevertheless, the mentioned benzofuran neolignans (1-4) were also found in a considerable amount of studies [18-23]. Apart from that, Felipe et al. [14] successfully developed and validated the quantitative determination of neolignans found in the extracts of $P$. regnellii. Specifically, the procedure confirmed that the developed technique can produce a reliable analysis of the neolignans and appropriate for the quality control of the extracts as well as phytopharmaceutical preparations concerning P. regnellii.

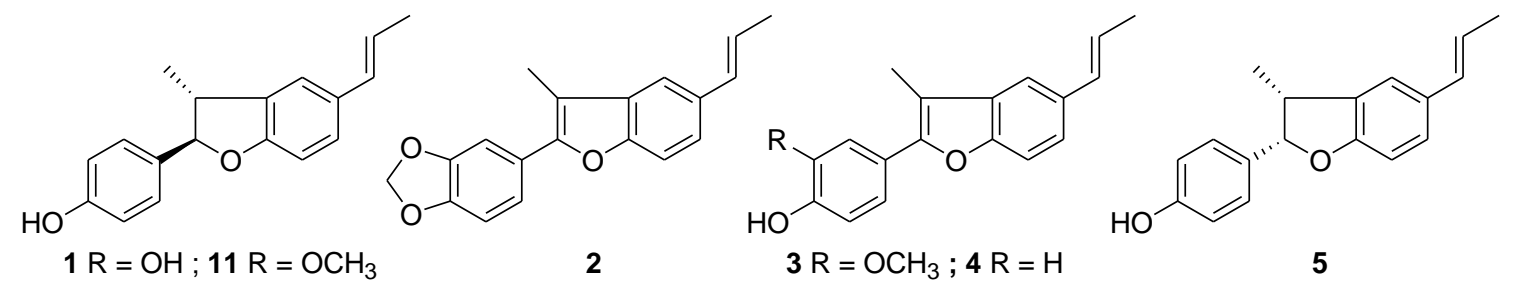

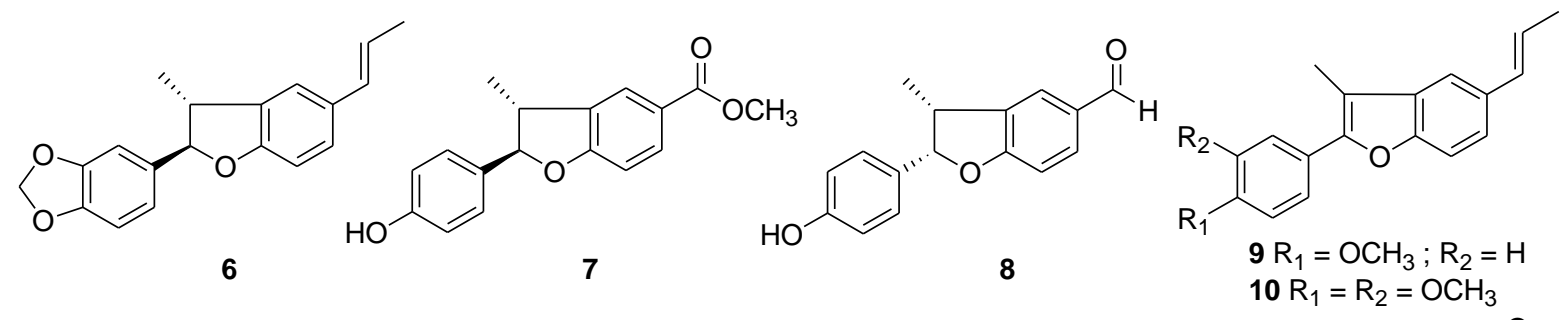<smiles>COc1cc(C2Oc3ccc(C=O)cc3C2C)ccc1O</smiles>

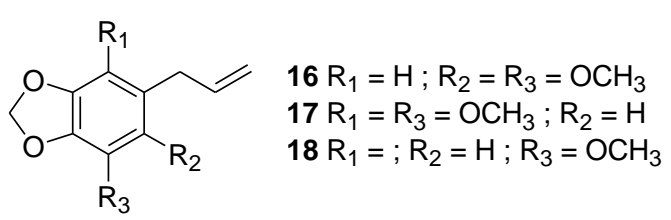

Figure 1. Chemical structures of isolated compounds from P. regnellii.

Meanwhile, research by Pessini et al. [18] successfully isolated 4'-(methoxyphenyl)-3methyl-5(E)-propenyl benzofuran (9), 2-(4',5'-dimethoxyphenyl)-3-methyl-5(E)-propenyl benzofuran (10), and (2R,3R)-2,3-dihydro-2-(4'-methoxyphenyl)-3-methyl-5(E)propenylbenzofuran (11), including compounds (1-4). Other than that, Ramos et al. [24] reported the isolation of decurrenal (12), 2-(4-hydroxyphenyl)-3-methyl-5benzofuranylcarboxylic acid (13), 3-[(2R,3R)-2,3-dihydro-3-(methyl)-2-(4-hydroxyphenyl)-5benzofuranyl]-(2E)-propenal (14), and (2R,3R)-2,3-dihydro-2-(3-methoxi-4-hydroxyphenyl)3-methyl-5-benzofurancarboxaldehyde (15), through the biotransformation of compounds (14) performed by the beetles. In this case, compounds (1-3) underwent oxidative cleavage of the ozonolysis type, followed by selective oxidation at the terminal methyl of the alkyl group for their respective aldehyde $(\mathbf{1 2}, \mathbf{1 4}$, and 15) as well as the acid (13) during their metabolism in Naupactus bipes. More importantly, previous phytochemical investigations demonstrated that Piper species is a very rich source of phenolic compounds comprised of phenylpropanoids [2527]. Nevertheless, in the case of $P$. regnellii, only in the study of Benevides et al. [17] that the phenylpropanoids were successfully identified. Specifically, they managed to isolate apiol (16), dillapiole (17), and myristicin (18) from the roots part of P. regnellii. On another note, 
the Piper genus is an extremely well-known and widely distributed pantropical taxon of aromatic plants.

\section{Essential oils}

The essential oils of plant origin have been used since ancient times. Essential oils are composed of secondary metabolites commonly concentrated in aromatic plants' leaves, bark, or fruit. As produced by aromatic plants, essential oils are commonly used in beverages, food, pharmaceutical, and cosmetics industries due to their documented medicinal properties. These oils are responsible for both the aroma and biological properties of medicinal plants. Researchers have pointed out that the volatile oils of different plant organs possess antitumorigenic, insecticidal, antifungal, anticarcinogenic, antibacterial, anti-inflammatory, antiparasitic, antiviral, and antioxidant properties [28-42]. As previously mentioned, the chemistry of $P$. regnellii essential oils, mainly from Brazil [43-51] has been extensively studied, as listed in Table 1. In the first study of essential oil from Brazilian P. regnellii, the occurrence of $\beta$-caryophyllene, $(E)$-nerolidol, spathulenol, and globulol in the aerial parts was reported [43]. On a similar note, Anderson et al. [51] reported that the highest percentage of a sesquiterpene, germacrene D was detected in P. regnellii leaves oil. In addition, Costantin et al. [44] described the presence of monoterpene from leaves with a predominance of myrcene, followed by other studies that reported the presence of myrcene as the major component [4547,49]. Regarding this matter, Ramos et al. [48] recorded the presence of monoterpene known as $\beta$-pinene, while the richness of phenylpropanoids was detected in the leaves, flowers, and stem oils of $P$. regnellii, which are respectively characterized as apiole, anethole $\mathrm{E}$, and dillapiole [49]. In a general sense, it can be understood that essential oils are rich in all classes of volatile chemical compounds. However, the composition for both inter and intra is highly variable, which further suggests that the differences are dependent on the polymorphism, plant part, geographical differences, environmental conditions, and chemotypes [52,53].

Table 1. Chemical components isolated from Brazillian P. regnellii essential oils

\begin{tabular}{|c|c|c|}
\hline Parts & Total identified & Major components \\
\hline $\begin{array}{l}\text { Aerial } \\
\text { parts }\end{array}$ & $28,96.5 \%$ & $\begin{array}{l}\beta \text {-Caryophyllene }(23.4 \%),(E) \text {-nerolidol }(13.7 \%) \text {, spathulenol }(11.1 \%) \text {, globulol } \\
(6.1 \%)[43]\end{array}$ \\
\hline Leaves & $25,98.7 \%$ & Myrcene $(52.60 \%)$, linalool $(15.89 \%), \beta$-caryophyllene $(8.50 \%)^{29,30}$ \\
\hline Leaves & $*$ nm & Myrcene (70\%) [46] \\
\hline Leaves & $19,91.51 \%$ & $\begin{array}{l}\text { Myrcene }(15.45 \%), \beta \text {-pinene }(13.34 \%) \text {, bicyclogermacrene }(9.66 \%),(E) \text { - } \\
\text { nerolidol }(8.37 \%), \text { aromadendrene }(8.27 \%), \text { spathulenol }(7.80 \%), \quad \beta \text { - } \\
\text { caryophyllene }(7.21 \%)[47]\end{array}$ \\
\hline Leaves & $30,83.1 \%$ & $\beta$-Pinene $(54.9 \%)$, linalool $(5.9 \%)[24]$ \\
\hline Leaves & $61,99 \%$ & $\begin{array}{l}\text { Myrcene (21.97\%), anethole } \mathrm{E}(16.01 \%), \\
\text { bicyclogermacrene }(9.43 \%), \text { junicedranol }(8.93 \%)[49]\end{array}$ \\
\hline Stems & $64,99 \%$ & $\begin{array}{l}\text { Dillapiole }(30.15 \%) \text {, myrcene }(14.9 \%) \text {, anethole E }(13.42 \%) \text {, junicedranol } \\
(7.91 \%)[49]\end{array}$ \\
\hline Flowers & $61,99 \%$ & $\begin{array}{l}\text { Anethole E }(28.24 \%) \text {, myrcene }(23.04 \%) \text {, bicyclogermacrene }(9.60 \%), \gamma \text { - } \\
\text { muurolene }(7.23 \%)[49]\end{array}$ \\
\hline Leaves & $*$ nm & Apiole (42.0\%), dillapiole (16.7\%) [50] \\
\hline Leaves & $28,>90 \%$ & Germacrene D (45.6\%), $\alpha$-chamigrene (8.9\%), $\beta$-caryophyllene $(8.2 \%)$ [51] \\
\hline
\end{tabular}




\section{Pharmacological studies}

A search of the literature revealed the occurrence of biological activities, including antimicrobial, antifungal, anticancer, anti-inflammatory, antileishmanial, wound healing, antiviral, and anti-biofilm activities. As can be observed, the bioactivities of the isolated compounds (1-4) [54-60] have been widely investigated, as listed in Table 2.

\subsection{Antimicrobial activity.}

In the study conducted by Marçal et al. [56], the ethyl acetate extract presented a good activity against Staphylococcus aureus MRSA with minimal inhibitory concentration (MIC) as well as minimal bactericidal concentration (MBC) of $16 \mu \mathrm{g} / \mathrm{mL}$. Accordingly, the leaves, roots, and stems extracts demonstrated good activity against Staphylococcus aureus and Bacillus subtilis, with MIC recorded between 31.25 - $62.5 \mu \mathrm{g} / \mathrm{mL}$. Moreover, the hydroalcoholic extract of the leaves was found to be more active than the stems and roots extracts despite the insignificant differences. Other than that, all extracts of $P$. regnellii in the anti-yeast assay displayed good activity against Candida tropicalis (MIC of $62.5 \mu \mathrm{g} / \mathrm{mL}$ ), followed by a moderate response against Candida albicans (MIC of $250 \mu \mathrm{g} / \mathrm{mL}$ ) [61]. In another case, the essential oil and ethanolic leaves/roots extracts of $P$. regnellii reported a weak anti-candida activity against Candida albicans CBMAI 0475 with MIC of $>2 \mu \mathrm{g} / \mathrm{mL}$ [62]. Similarly, a weak activity against Candida albicans (MIC of $125 \mu \mathrm{g} / \mathrm{mL}$ ) was found in the aerial part extract as published in a study conducted by Johann et al. [63]. In addition, Holetz et al. [64] reported that $P$. regnellii extract exhibited activity against the yeasts Candida krusei (MIC of 125 $\mu \mathrm{g} / \mathrm{mL}$ ) and Candida tropicalis (MIC of $500 \mu \mathrm{g} / \mathrm{mL}$ ). More importantly, the ethanolic leaves extract of $P$. regnellii showed strong activity against the bacteria Staphylococcus aureus (MIC of $7.8 \mu \mathrm{g} / \mathrm{mL}$ ) as well as Bacillus subtilis (MIC of $15.6 \mu \mathrm{g} / \mathrm{mL}$ ). However, the aqueous extract displayed a weak activity against Staphylococcus aureus and Bacillus subtilis with MIC and MBC of $1000 \mu \mathrm{g} / \mathrm{mL}$. In addition, the ethyl acetate extract in a study of Pessini et al. [18] presented a good activity against $S$. aureus and B. subtilis with MIC and MBC at $15.62 \mu \mathrm{g} / \mathrm{mL}$.

Table 2. Pharmacological studies of isolated compounds from $P$. regnellii.

\begin{tabular}{|c|c|c|}
\hline Compounds & Bioactivities & Description \\
\hline \multirow[t]{5}{*}{ Conocarpan (1) } & Anti-biofilm & $\begin{array}{l}\text { Exhibited a good activity against Staphylococcus aureus MRSA } \\
\text { and } S \text {. aureus MSSA with MIC of } 50 \mu \mathrm{g} / \mathrm{mL} \text { and MBC of } 100 \\
\mu \mathrm{g} / \mathrm{mL}[54]\end{array}$ \\
\hline & Antiproliferative & $\begin{array}{l}\text { Presented considerable activity against epimastigote forms of } \\
\text { Trypanosoma cruzi with } \mathrm{IC}_{50} \text { of } 8.0 \mathrm{mg} / \mathrm{mL}[20]\end{array}$ \\
\hline & Antibacterial & $\begin{array}{l}\text { Presented quite active against } S \text {. aureus and B. subtilis with MIC } \\
\text { of } 6.25 \mu \mathrm{g} / \mathrm{mL}[18]\end{array}$ \\
\hline & Antifungal & $\begin{array}{l}\text { Exhibited a strong activity against } C \text {. albicans, } C . \text { krusei, } C \text {. } \\
\text { parapsilosis, and } C \text {. tropicalis with MIC value } 6.3,12.5,25 \text {, and } \\
6.3 \mu \mathrm{g} / \mathrm{mL} \text {, respectively [19] }\end{array}$ \\
\hline & $\begin{array}{l}\text { Anti- } \\
\text { tuberculosis }\end{array}$ & $\begin{array}{l}\text { Exhibited a strong activity against Mycobacterium tuberculosis } \\
\text { with MIC of } 15.6 \mu \mathrm{g} / \mathrm{mL}[55]\end{array}$ \\
\hline \multirow[t]{3}{*}{ Eupomathenoid-3 (2) } & Antimicrobial & Presented MIC of $16 \mu \mathrm{g} / \mathrm{mL}$ against $S$. aureus MRSA [56] \\
\hline & \multirow[t]{2}{*}{ Antifungal } & $\begin{array}{l}\text { Exhibited a strong activity on Trichophyton rubrum with MIC of } \\
50 \mu \mathrm{g} / \mathrm{mL}[15]\end{array}$ \\
\hline & & $\begin{array}{l}\text { Exhibited a moderate activity against } C \text {. albicans, } C \text {. krusei, } C \text {. } \\
\text { parapsilosis, and } C \text {. tropicalis with MIC value }>100 \mu \mathrm{g} / \mathrm{mL} \text {, each } \\
{[19]}\end{array}$ \\
\hline
\end{tabular}




\begin{tabular}{|c|c|c|}
\hline Compounds & Bioactivities & Description \\
\hline & $\begin{array}{l}\text { Anti- } \\
\text { tuberculosis }\end{array}$ & $\begin{array}{l}\text { Displayed weak activity against Mycobacterium tuberculosis with } \\
\text { MIC of } 250 \mu \mathrm{g} / \mathrm{mL} \text { [55] }\end{array}$ \\
\hline \multirow[t]{11}{*}{ Eupomathenoid-5 (3) } & $\begin{array}{l}\text { Anti- } \\
\text { tuberculosis }\end{array}$ & $\begin{array}{l}\text { Exhibited a strong activity with } \mathrm{MIC} \text { of } 1.9 \mu \mathrm{g} / \mathrm{mL} \text { on } \\
\text { Mycobacterium tuberculosis } \mathrm{H} 37 \mathrm{Rv} \text { and a good selectivity index } \\
\text { of } 20.0 \text { [55] }\end{array}$ \\
\hline & Anti-biofilm & $\begin{array}{l}\text { Exhibited a good activity against } S \text {. aureus MRSA and } S \text {. aureus } \\
\text { MSSA with MIC of } \leq 6.25 \mu \mathrm{g} / \mathrm{mL} \text { and } \mathrm{MBC} \text { of }<25 \mu \mathrm{g} / \mathrm{mL} \text { [54] }\end{array}$ \\
\hline & Anticancer & $\begin{array}{l}\text { Exhibited a strong activity against kidney, ovary, prostate, and } \\
\text { breast cell lines, with TGI values of } 1.93,5.50,6.17 \text {, and } 6.24 \\
\mu \mathrm{g} / \mathrm{mL} \text {, respectively [22] }\end{array}$ \\
\hline & Antiviral & $\begin{array}{l}\text { Inactive against bovine herpesvirus-1 (BHV-1) and poliovirus } \\
\text { viruses with } \mathrm{EC}_{50} \text { value }>50 \mu \mathrm{g} / \mathrm{mL} \text { [57] }\end{array}$ \\
\hline & Antibacterial & $\begin{array}{l}\text { Exhibited a good activity against } S . \text { aureus and B. subtilis with } \\
\text { MIC of } 3.12 \mu \mathrm{g} / \mathrm{mL} \text {, each [18] }\end{array}$ \\
\hline & \multirow[t]{2}{*}{ Antiproliferative } & $\begin{array}{l}\text { Presented considerable activity against epimastigote forms of } \\
\text { Trypanosoma cruzi with } \mathrm{IC}_{50} \text { of } 7.0 \mathrm{mg} / \mathrm{mL}[20]\end{array}$ \\
\hline & & $\begin{array}{l}\text { Exhibited activity against trypomastigotes, the infective form of } \\
\text { Trypanosoma cruzi }\left(\mathrm{EC}_{50} \text { of } 40.5 \mathrm{mM}\right) \text {, leading to ultrastructural } \\
\text { alteration and lipoperoxidation in the cell membrane [58] }\end{array}$ \\
\hline & \multirow[t]{2}{*}{ Antileishmanial } & $\begin{array}{l}\text { The compound shows the incubation of Leishmania amazonensis } \\
\text { promastigotes for } 3 \text { and } 24 \mathrm{~h} \text { resulted in a } 16 \% \text { increase in the } \\
\text { proportion of cells in the sub-G0/G1 phase at the lower } \\
\text { concentration }(30 \mu \mathrm{M}) \text { and a } 28 \% \text { increase at the higher } \\
\text { concentrations }(85 \text { and } 170 \mu \mathrm{M})[59]\end{array}$ \\
\hline & & $\begin{array}{l}\text { Exhibited a dose-dependent activity during } 72 \mathrm{~h} \text { of treatment with } \\
\mathrm{IC}_{50} \text { of } 9.0 \mu \mathrm{g} / \mathrm{mL} \text { and } 13.0 \mu \mathrm{g} / \mathrm{mL} \text { for promastigote and axenic } \\
\text { amastigote forms, respectively, and } \mathrm{IC}_{50} \text { of } 5.0 \mu \mathrm{g} / \mathrm{mL} \text { for } \\
\text { intracellular amastigote forms of Leishmania amazonensis [60] }\end{array}$ \\
\hline & \multirow[t]{2}{*}{ Antifungal } & $\begin{array}{l}\text { Exhibited a strong activity on Trichophyton rubrum with MIC of } \\
6.2 \mu \mathrm{g} / \mathrm{mL}[15]\end{array}$ \\
\hline & & $\begin{array}{l}\text { Displayed a moderate activity against } C \text {. albicans, } C \text {. krusei, } C \text {. } \\
\text { parapsilosis, and } C \text {. tropicalis with MIC value }>100 \mu \mathrm{g} / \mathrm{mL} \text {, each } \\
{[19]}\end{array}$ \\
\hline \multirow[t]{3}{*}{ Eupomathenoid-6 (4) } & Antiproliferative & $\begin{array}{l}\text { Presented considerable activity against epimastigote forms of } \\
\text { Trypanosoma cruzi with } \mathrm{IC}_{50} \text { of } 7.5 \mathrm{mg} / \mathrm{mL}[20]\end{array}$ \\
\hline & Antibacterial & $\begin{array}{l}\text { Displayed a good activity against } S . \text { aureus (MIC of } 1.56 \mu \mathrm{g} / \mathrm{mL} \text { ) } \\
\text { and B. subtilis (MIC of } 3.12 \mu \mathrm{g} / \mathrm{mL} \text { ) [18] }\end{array}$ \\
\hline & Antifungal & $\begin{array}{l}\text { Displayed moderate activity against } C \text {. albicans, } C \text {. krusei, } C \text {. } \\
\text { parapsilosis, and } C \text {. tropicalis with MIC value }>100 \mu \mathrm{g} / \mathrm{mL}[19]\end{array}$ \\
\hline
\end{tabular}

\subsection{Antifungal activity.}

Research by Johann et al. [65] showed that the leaves extracts of $P$. regnelli had strong antifungal activity against pathogenic fungus Paracoccidioides brasiliensis with MIC of 7.8 $\mu \mathrm{g} / \mathrm{mL}$. Meanwhile, a similar result of strong activity was found in the hydroalcoholic leaves extract of $P$. regnellii against the dermatophyte fungi Trichophyton mentagrophytes, Trichophyton rubrum, Microsporum canis, and Microsporum gypseum with their respective MICs of $15.62,15.62,15.62$, and $62.5 \mu \mathrm{g} / \mathrm{mL}$ [15]. On a similar note, the same authors conducted another study two years later and reported that the dichloromethane and chloroform extracts showed strong activity against Trichophyton rubrum with MIC of $7.8 \mu \mathrm{g} / \mathrm{mL}$ [66]. Research by Lemos et al. [23] reported that the leaves extract of $P$. regnellii showed strong activity against Trichophyton mentagrophytes and Trichophyton rubrum at $40^{\circ} \mathrm{C}$ and $25 \mathrm{MPa}$ 
with the MIC of $7.8 \mu \mathrm{g} / \mathrm{mL}$. Meanwhile, Pessini et al. [19] recorded a significant activity in the EtOAc extract against Candida albicans with MIC of $125 \mu \mathrm{g} / \mathrm{mL}$, while moderate activity was detected against both $C$. krusei and C. parapsilosis with MIC of $500 \mu \mathrm{g} / \mathrm{mL}$. However, it is important to note that Candida tropicalis is not able to be inhibited by this extract at a concentration as high as $1000 \mu \mathrm{g} / \mathrm{mL}$.

\subsection{Anticancer activity.}

In vitro studies conducted by Longato et al. [22] revealed that $P$. regnellii dichloromethane extract was effective against almost all human tumor cell lines, including melanoma (UACC-62) (TGI of $26.45 \mu \mathrm{g} / \mathrm{mL}$ ), breast (MCF7) (TGI of $39.58 \mu \mathrm{g} / \mathrm{mL}$ ), kidney (786-0) (TGI of $21.93 \mu \mathrm{g} / \mathrm{mL}$ ), lung (NCI-H460) (TGI of $20.39 \mu \mathrm{g} / \mathrm{mL}$ ), prostate (PC-3) (TGI of $10.97 \mu \mathrm{g} / \mathrm{mL}$ ), ovary (OVCAR-3) (TGI of $12.05 \mu \mathrm{g} / \mathrm{mL}$ ), colon (HT29) (TGI of 42.09 $\mu \mathrm{g} / \mathrm{mL}$ ), and leukemia (K-562) (TGI of $158.44 \mu \mathrm{g} / \mathrm{mL}$ ) cell lines.

\subsection{Anti-inflammatory activity.}

A study by Schmidt et al. [67] examined the anti-inflammatory activity against NF-kB DNA binding, p38 $\alpha$, and TNF- $\alpha$ release in whole blood. In NF-kB DNA binding, the hexane extract showed strong inhibition ( $>70 \%$ ) of DNA binding at $100 \mu \mathrm{g} / \mathrm{mL}$, whereas the ethanol extract was found inactive $(<30 \%)$. In the case of p38 $\alpha$ assay, the hexane and ethanol extracts recorded the inhibition percentage of $61.88 \%$ and $48.63 \%$, respectively. Next, the hexane extract in TNF- $\alpha$ assay showed weak activity with an inhibition percentage of $5.98 \%$.

\subsection{Antileishmanial activity.}

In the case of antileishmanial activity, the leaves extract of $P$. regnellii showed a high percentage of growth inhibition at $98.2 \%$ and $96.8 \%$ against axenic amastigote and promastigote forms of Leishmania amazonensis, respectively. In addition, the extract showed strong inhibition against epimastigote forms of Trypanosoma cruzi with the inhibition growth of $89.7 \%$ at a concentration of $100 \mu \mathrm{g} / \mathrm{mL}$ [68].

\subsection{Wound healing (scratch) activity.}

Schmidt et al. [67] conducted a study to investigate the influence of the extracts on fibroblasts' migration and proliferation into the wounded monolayer of the scratch assay against swiss $3 \mathrm{~T} 3$ mouse fibroblasts. The ethanolic extracts of $P$. regnellii at a $10 \mu \mathrm{g} / \mathrm{mL}$ concentration showed a weak activity with the percentage stimulation of $22.11 \%$, whereas the hexane extract was found inactive.

\subsection{Antiviral activity.}

Research by Bertol et al. [57] detected antiviral activity in hexane, chloroform, chloroform/ethyl acetate (19:1), and chloroform/ethyl acetate (9:1) fractions against bovine herpesvirus-1 (BHV-1). Similarly, the chloroform, chloroform/ethyl acetate (19:1), chloroform/ethyl acetate (9:1), chloroform/ethyl acetate (1:1), and ethyl acetate fractions were found to be active against poliovirus. 


\subsection{Anti-biofilm activity.}

The dichloromethane leaves extract of $P$. regnellii showed a good effect against the isolated methicillin-sensitive $S$. aureus biofilms (MIC of $15.6 \mu \mathrm{g} / \mathrm{mL}$ ) as well as $S$. aureus planktonic cells (MIC of $<12.5 \mu \mathrm{g} / \mathrm{mL}$ ) [54].

\section{Conclusions}

The overall review of the literature revealed neolignans in $P$. regnellii as the major class, which is rich in conocarpan, eupomatenoid-3, eupomatenoid-5, and eupomatenoid-6. Meanwhile, it is important to note that the overall biological investigations of $P$. regnellii have not been well investigated except for some preliminary works regarding in vitro screenings. Hence, the isolated compounds could only be found in various pharmacological studies. Accordingly, this seems to suggest valuable potential constituents for drug development. In conclusion, in-depth investigations of $P$. regnellii are recommended, especially concerning both the in vivo and in vitro pharmacological evaluations of the extracts and constituents deemed valuable and encouraging.

\section{Funding}

This research was supported by the Ministry of Education (MOE) through the Fundamental Research Grant Scheme for Research Acculturation of Early Career Researchers (FRGSRACER/1/2019/STG01/UPSI/1).

\section{Acknowledgments}

The authors would like to thank the Department of Chemistry, Faculty of Science and Mathematics, Universiti Pendidikan Sultan Idris for research facilities.

\section{Conflicts of Interest}

The authors declare no conflict of interest.

\section{References}

1. Hong, J.Y. Natural product diversity and its role in chemical biology and drug discovery. Curr. Opin. Chem. Biol. 2011, 15, 350-354, https://doi.org/10.1016/j.cbpa.2011.03.004.

2. Galm, U.; Shen, B. Natural product drug discovery: The times have never been better. Chem. Biol. 2007, 14, 1098-1104, https://doi.org/10.1016/j.chembiol.2007.10.004.

3. Yuan, H.; Ma, Q.; Ye, L.; Piao, G. The traditional medicine and modern medicine from natural products. Molecules 2016, 21, 559-577, https://doi.org/10.3390/molecules21050559.

4. Cragg, G.M.; Newman, D.J. Natural products: a continuing source of novel drug leads. Biochim. Biophys. Acta 2013, 1830, 3670-3695, https://doi.org/10.1016/j.bbagen.2013.02.008.

5. Salleh, W.M.N.H.W.; Ahmad, F.; Khong, H.Y.; Sirat, H.M. Chemical compositions, antioxidant and antimicrobial activities of the essential oils of Piper caninum Blume. Int. J. Mol. Sci. 2011, 12, 7720-7731, https://doi.org/10.3390/ijms12117720.

6. Salleh, W.M.N.H.W.; Ahmad, F.; Khong, H.Y.; Sirat, H.M. Chemical compositions, antioxidant and antimicrobial activities of the essential oils of Piper officinarum C.DC (Piperaceae). Nat. Prod. Commun. 2012, 7, 1659-1662, https://doi.org/10.1177/1934578X1200701229.

7. Ahmad, F.; Salleh, W.M.N.H.W.; Sirat, H.M.; Yen, K.H. Chemical compositions and antibacterial activity of the leaf and stem oils of Piper porphyrophyllum (Lindl.) N.E.Br. Excli. J. 2012, 11, 399-406, https://doi.org/10.17877/DE290R-4900. 
8. Salleh, W.M.N.H.W.; Ahmad, F.; Khong, H.Y. Chemical composition of Piper stylosum Miq. and Piper ribesioides Wall. essential oils and their antioxidant, antimicrobial and tyrosinase inhibition activities. $B$. Latinoam. Caribe Pl. 2014, 13, 488-497.

9. Salleh, W.M.N.H.W.; Ahmad, F.; Khong, H.Y. Chemical compositions and antimicrobial activity of the essential oils of Piper abbreviatum, P. erecticaule and P. lanatum (Piperaceae). Nat. Prod. Commun. 2014, 9, 1795-1798, https://doi.org/10.1177/1934578X1400901235.

10. Salleh, W.M.N.H.W.; Hashim, N.A.; Ahmad, F.; Khong, H.Y. Anticholinesterase and antityrosinase activities of ten Piper species from Malaysia. Adv. Pharm. Bull. 2014, 4, 527-531, https://doi.org/10.5681/apb.2014.078.

11. Salleh, W.M.N.H.W.; Kamil, F.; Ahmad, F.; Sirat, H.M. Antioxidant and anti-inflammatory activities of essential oil and extracts of Piper miniatum. Nat. Prod. Commun. 2015, 10, 2005-2008, https://doi.org/10.1177/1934578X1501001151.

12. Salleh, W.M.N.H.W.; Ahmad, F.; Khong, H.Y. Essential oil compositions and antimicrobial activity of Piper arborescens Roxb. Marmara Pharm. J. 2016, 20, 111-115, https://doi.org/10.12991/mpj.20162071871.

13. Salleh, W.M.N.H.W.; Abdullah, N.; Hashim, N.A.; Khong, H.Y.; Khamis, S. Aporphine alkaloids from Piper erecticaule and acetylcholinesterase inhibitory activity. B. Latinoam. Caribe Pl. 2019, 18, 527-532, https://doi.org/10.35588/blacpma.19.18.5.35.

14. Felipe, D.F.; Filho, B.P.D.; Nakamura, C.V.; Franco, S.L.; Cortez, D.A.G. Analysis of neolignans compounds of Piper regnellii (Miq.) C.DC. var. pallescens (C.DC.) Yunck by HPLC. J. Pharm. Biomed. Anal. 2006, 41, 1371-1375, https://doi.org/10.1016/j.jpba.2006.02.029.

15. Koroishi, A.M.; Foss, S.R.; Cortez, D.A.G.; Ueda-Nakamura, T.; Nakamura, C.V.; Dias-Filho, B.P. In vitro antifungal activity of extracts and neolignans from Piper regnellii against dermatophytes. J. Ethnopharmacol. 2008, 117, 270-277, https://doi.org/10.1016/j.jep.2008.01.039.

16. Macedo, A.L.; Dos Santos, T.C.C.; Valverde, A.L.; Moreira, D.L.; Vasconcelos, T.R.A. An overview of neolignans of the genus Piper L.: Isolation methods and biological activities. Mini Rev. Med. Chem. 2017, 17, 693-720, https://doi.org/10.2174/1389557516666161130094826.

17. Benevides, P.J.C.; Sartorelli, P.; Kato, M.J. Phenylpropanoids and neolignans from Piper regnellii. Phytochemistry 1999, 52, 339-343, https://doi.org/10.1016/S0031-9422(99)00177-6.

18. Pessini, G.L.; Dias Filho, B.P.; Nakamura, C.V.; Garcia Cortez, D.A. Antibacterial activity of extracts and neolignans from Piper regnellii (Miq.) C.DC. var. pallescens (C.DC.) Yunck. Mem. do Inst. Oswaldo Cruz 2003, 98, 1115-11120, https://doi.org/10.1590/s0074-02762003000800025.

19. Pessini, G.L.; Dias Filho, B.P.; Nakamura, C.V.; Cortez, D.A.G. Antifungal activity of the extracts and neolignans from Piper regnellii (Miq.) C.DC. var. pallescens (C.DC.) Yunck. J. Braz. Chem. Soc. 2005, 16(6A), 1130-1133, https://doi.org/10.1590/S0103-50532005000700007.

20. Luize, P.S.; Ueda-Nakamura, T.; Dias Filho, B.P.; Cortez, D.A.G.; Nakamura, C.V. Activity of neolignans isolated from Piper regnellii (Miq.) C.DC. var. pallescens (C.DC.) Yunck against Trypanosoma cruzi. Biol. Pharm. Bull. 2006, 29, 2126-2130, https://doi.org/10.1248/bpb.29.2126.

21. Marçal, F.J.B.; Cortez, D.A.G.; Ueda-Nakamura, T.; Nakamura, C.V.; Filho, B.P.D. Activity of the extracts and neolignans from Piper regnellii against methicillin-resistant Staphylococcus aureus (MRSA). Molecules 2010, 15, 2060-2069, https://doi.org/10.3390/molecules15042060.

22. Longato, G.B.; Rizzo, L.Y.; De Oliveira Sousa, I.M.; Tinti, S.V.; Possenti, A.; Figueira, G.M.; Ruiz, A.L.T.G.; Foglio, M.A.; De Carvalho, J.E. In vitro and in vivo anticancer activity of extracts, fractions, and eupomatenoid-5 obtained from Piper regnellii leaves. Planta Med. 2011, 77, 1482-1488, https://doi.org/10.1055/s-0030-1270889.

23. Lemos, C.O.T.; Svidzinsk, T.I.E.; Baeza, L.C.; Miranda, N.; Nakamura, C.V.; Cortez, D.A.G.; CardozoFilho, L.; Cabral, V.F. Evaluation of antifungal activity of extracts of Piper regnellii obtained by supercritical fluid extraction. Nat. Prod. Res. 2013, 27, 2355-2359, https://doi.org/10.1080/14786419.2013.830215.

24. Ramos, C.S.; Kato, M.J. Metabolism of neolignans from P. regnellii (Piperaceae) in the beetle Naupactus bipes (Coleoptera: Curculionidae). Chemoecology 2013, 23, 143-148, https://doi.org/10.1007/s00049-0130129-y.

25. Ghosh, K.; Bhattacharya, T.K. Chemical constituents of Piper betle Linn. (Piperaceae) roots. Molecules 2005 , 10, 798-802, https://doi.org/10.3390/10070798.

26. Ali, I.; Khan, F.G.; Suri, K.A.; Gupta, B.D.; Satti, N.K.; Dutt, P.; Afrin, F.; Qazi, G.N.; Khan, I.A. In vitro antifungal activity of hydroxychavicol isolated from Piper betle L. Ann. Clin. Microbiol. Antimicrob. 2010, 9, 1-9, https://doi.org/10.1186/1476-0711-9-7. 
27. Musa, T.A.; Sanagi, M.M.; Ibrahim, W.A.; Ahmad, F.; Aboul-Enein, H.Y. Determination of 4-allyl resorcinol and chavibetol from Piper betle leaves by subcritical water extraction combined with high performance liquid chromatography. Food Anal. Method 2014, 7, 893-901, https://doi.org/10.1007/s12161-013-9697-2.

28. Salleh, W.M.N.H.W.; Khamis, S.; Abed, S.A. Characterization of volatile components of Chassalia chartacea and its acetylcholinesterase inhibitory activity. Chem. Nat. Compd. 2021, 57, 319-320, https://doi.org/10.1007/s10600-021-03362-6.

29. Azhar, M.A.M.; Salleh, W.M.N.H.W.; Khamis, S. Essential oil composition of Beilschmiedia insignis from Malaysia. Chem. Nat. Compd. 2021, 57, 317-318, https://doi.org/10.1007/s10600-021-03361-7.

30. Salleh, W.M.N.H.W.; Khamis, S.; Rahman, M.N.A.; Nafiah, MA. Chemical composition and acetylcholinesterase activity of the essential oil of Anisophyllea disticha. Chem. Nat. Compd. 2021, 57, 315316, https://doi.org/10.1007/s10600-021-03360-8.

31. Salleh, W.M.N.H.W.; Khamis, S.; Kassim, H.; Tawang, A. Essential oil composition of Strychnos axillaris Colebr. (Loganiaceae). Nat. Vol. Essent. Oils 2021, 8, 13-17.

32. Salleh, W.M.N.H.W.; Shaharudin, S.M. Multivariate statistical analysis of the essential oils of five Beilschmiedia species from Peninsular Malaysia. Latin Am. Carib. Bull. Med. Arom. Pl. 2021, 26, 61-70.

33. Anuar, M.Z.A.; Salleh, W.M.N.H.W.; Khamis, S.; Nafiah, M.A.; Said, Z.M. Essential oil composition of Alseodaphne perakensis (Gamble) Kosterm from Malaysia. Nat. Prod. Res. 2021, 35, 508-511, https://doi.org/10.1080/14786419.2019.1636245.

34. Salleh, W.M.N.H.W.; Khamis, S.; Nadri, M.H.; Kassim, H.; Tawang, A. Essential oil composition and antioxidant activity of Reinwardtiodendron cinereum Mabb. (Meliaceae). Nat. Vol. Essent. Oils 2020, 7, 17, https://doi.org/10.37929/nveo.770245.

35. Salleh, W.M.N.H.W.; Khamis, S.; Nadri, M.H.; Kassim, H.; Tawang, A. Chemical composition and acetylcholinesterase inhibition of the essential oil of Cyathocalyx pruniferus (Maingay ex Hook.f. \& Thomson) J.Sinclair. Nat. Vol. Essent. Oils 2020, 7, 8-13, https://doi.org/10.37929/nveo.770303.

36. Salleh, W.M.N.H.W.; Khamis, S. Chemical composition of Sarcotheca laxa (Ridl.) Knuth essential oil and their bioactivities. Riv. Ital. Delle Sost. Gras. 2020, 97, 11-16.

37. Shakri, N.M.; Salleh, W.M.N.H.W.; Khamis, S.; Ali, N.A.M. Chemical characterization of Goniothalamus macrophyllus and Goniothalamus malayanus leaves' essential oils. Z. Naturforsch. C - J Biosci. 2020, 75 , 485-488, https://doi.org/10.1515/znc-2020-0090.

38. Shakri, N.M.; Salleh, W.M.N.H.W.; Khamis, S.; Ali, N.A.M. Composition of the essential oils of three Malaysian Xylopia species (Annonaceae). Z. Naturforsch. C - J Biosci. 2020, 75, 479-484, https://doi.org/10.1515/znc-2020-0096.

39. Shakri, N.M.; Salleh, W.M.N.H.W.; Khamis, S.; Ali, N.A.M.; Shaharudin, S.M. Chemical composition of the essential oils of four Polyalthia species from Malaysia. Z. Naturforsch. C - J Biosci. 2020, 75, 473-478, https://doi.org/10.1515/znc-2020-0097.

40. Salleh, W.M.N.H.W.; Khamis, S. Chemical composition of the essential oil of Diospyros wallichii King \& Gamble (Ebenaceae). Nat. Vol. Essent. Oils 2020, 7, 12-17.

41. Salleh, W.M.N.H.W.; Khamis, S. Chemical composition and anticholinesterase inhibitory activity of Pavetta graciliflora Wall. ex Ridl. essential oil. Z. Naturforsch. C - J Biosci. 2020, 75, 467-471, https://doi.org/10.1515/znc-2020-0075.

42. Azhar, M.A.M.; Salleh, W.M.N.H.W.; Khamis, S. Essential oil composition of three Cryptocarya species from Malaysia. Z. Naturforsch. C - J Biosci. 2020, 75, 297-301, https://doi.org/10.1515/znc-2020-0079.

43. Andrade, E.H.A.; Zoghbi, M.D.G.B.; Santos, A.S.; Maia, J.G.S. Essential oils of Piper gaudichaudianum Kunth and P. regnellii (Miq.) C.DC. J. Essent. Oil Res. 1998, 10, 465-467, https://doi.org/10.1080/10412905.1998.9700945.

44. Costantin, M.B.; Sartorelli, P.; Limberger, R.; Henriques, A.T.; Steppe, M.; Ferreira, M.J.P.; Ohara, M.T.; Emerenciano, V.P.; Kato, M.J. Essential oils from Piper cernuum and Piper regnellii: Antimicrobial activities and analysis by GC/MS and 13C-NMR. Planta Med. 2001, 67, 771-773, https://doi.org/10.1055/s-200118363.

45. Ferreira, M.J.P.; Costantin, M.B.; Sartorelli, P.; Rodrigues, G.V.; Limberger, R.; Henriques, A.T.; Kato, M.J.; Emerenciano, V.P. Computer-aided method for identification of components in essential oils by ${ }^{13} \mathrm{C}$ NMR spectroscopy. Anal. Chim. Acta 2001, 447, 125-134, https://doi.org/10.1016/S0003-2670(01)01204-1.

46. Pessini, L.; Dias Filho, B.P.; Nakamura, C.V.; Ferreira, A.G.; Cortez, D.A.G. Neolignanas e análise do óleo essencial das folhas de Piper regnellii (Miq.) C.DC. var. pallescens (C. DC.) Yunck. Braz. J. Pharmacogn. 2005, 15, 199-204, https://doi.org/10.1590/S0102-695X2005000300006. 
47. Morandim-Giannetti, A.A.; Pin, A.R.; Pietro, N.A.S.; de Oliveira, H.C.; Mendes-Giannini, M.J.S.; Alecio, A.C.; Kato, M.J.; de Oliveira, J.E.; Furlan, M. Composition and antifungal activity against Candida albicans, Candida parapsilosis, Candida krusei and Cryptococcus neoformans of essential oils from leaves of Piper and Peperomia species. J. Med. Pl. Res. 2010, 4, 1810-1814.

48. Ramos, C.S.; Soares, M.G.; Da Silva, A.M.; Batista-Pereira, L.G.; Corrêa, A.G.; Kato, M.J. Electrophysiological responses of the Naupactus bipes beetle to essential oils from Piperaceae species. Nat. Prod. Commun. 2012, 7, 1103-1106, https://doi.org/10.1177/1934578X1200700835.

49. dos Santos, A.L.; Polidoro, A.D.S.; Schneider, J.K.; da Cunha, M.E.; Saucier, C.; Jacques, R.A.; Cardoso, C.A.L.; Mota, J.S.; Caramão, E.B. Comprehensive two-dimensional gas chromatography time-of-flight mass spectrometry (GC $\times$ GC/TOFMS) for the analysis of volatile compounds in Piper regnellii (Miq.) C.DC. essential oils. Microchem. J. 2015, 118, 242-251, https://doi.org/10.1016/j.microc.2014.07.007.

50. Cruz. S.M.; Caceres, A.; Alvarez, L.E.; Apel, M.A.; Henriques, A.T. Chemical diversity of essential oils of 15 Piper species from Guatemala. Acta Horticult. 2012, 964, 39-46, https://doi.org/10.17660/ActaHortic.2012.964.4

51. Anderson, R.R.; Girola, N.; Figueiredo, C.R.; Londero, V.S.; Lago, J.H.G. Circadian variation and in vitro cytotoxic activity evaluation of volatile compounds from leaves of Piper regnellii (Miq) C.DC. var. regnellii (C.DC.) Yunck (Piperaceae). Nat. Prod. Res. 2018, 32, 859-862, https://doi.org/10.1080/14786419.2017.136195.

52. da Silva, J.K.; da Trindade, R.; Alves, N.S.; Figueiredo, P.L.; Maia, J.G.S.; Setzer, W.N. Essential oils from Neotropical Piper species and their biological activities. Int. J. Mol. Sci. 2017, 18, 2571-2613, https://doi.org/10.3390/ijms18122571.

53. Thin, D.B.; Chinh, H.V.; Luong, N.X.; Hoi, T.M.; Dai, D.N.; Ogunwande, I.A. Chemical analysis of essential essential oils of Piper laosanum and Piper acre (Piperaceae) from Vietnam. J. Essent. Oil Bear. Pl. 2018, 21, 181-188, https://doi.org/10.1080/0972060X.2018.1424040.

54. Brambilla, L.Z.S.; Endo, E.H.; Cortez, D.A.G.; Filho, B.P.D. Anti-biofilm activity against Staphylococcus aureus MRSA and MSSA of neolignans and extract of Piper regnellii. Braz. J. Pharmacogn. 2017, 27, 112117, https://doi.org/10.1016/j.bjp.2016.08.008.

55. Scodro, R.B.; Pires, C.T.; Carrara, V.S.; Lemos, C.O.; Cardozo-Filho, L.; Souza, V.A.; Corrêa, A.G.; Siqueira, V.L.; Lonardoni, M.V.; Cardoso, R.F.; Cortez, D.A. Anti-tuberculosis neolignans from Piper regnellii. Phytomedicine 2013, 20, 600-604, https://doi.org/10.1016/j.phymed.2013.01.005.

56. Marçal, F.J.B.; Cortez, D.A.G.; Ueda-Nakamura, T.; Nakamura, C.V.; Filho, B.P.D. Activity of the extracts and neolignans from Piper regnellii against methicillin-resistant Staphylococcus aureus (MRSA). Molecules 2010, 15, 2060-2069, https://doi.org/10.3390/molecules15042060.

57. Bertol, J.W.; Santos, P.R.; Rodrigues, J.; Cortez, D.A.G.; Filho, D.; Benedito, P.; Nakamura, C.V.; UedaNakamura, T. Antiviral activity of fractions from leaves of Piper regnelli var. pallescens. Rev. Bras. de Farmacogn. 2012, 22, 1276-1281, https://doi.org/10.1590/S0102-695X2012005000110.

58. Pelizzaro-Rocha, K.J.; Veiga-Santos, P.; Lazarin-Bidóia, D.; Ueda-Nakamura, T.; Dias Filho, B.P.; Ximenes, V.F.; Silva, S.O.; Nakamura, C.V. Trypanocidal action of eupomatenoid-5 is related to mitochondrion dysfunction and oxidative damage in Trypanosoma cruzi. Microbes. Infect. 2011, 13, 1018-1024, https://doi.org/10.1016/j.micinf.2011.05.011.

59. Garcia, F.P.; Lazarin-Bidóia, D.; Ueda-Nakamura, T.; Silva, S.D.O.; Nakamura, C.V. Eupomatenoid-5 isolated from leaves of Piper regnellii induces apoptosis in Leishmania amazonensis. Evid. Based Complement. Altern. Med. 2013, 940531, https://doi.org/10.1155/2013/940531.

60. Vendrametto, M.C.; Santos, A.O.; Nakamura, C.V.; Filho, B.P.D.; Cortez, D.A.G.; Ueda-Nakamura, T. Evaluation of antileishmanial activity of eupomatenoid-5, a compound isolated from leaves of Piper regnellii var. pallescens. Parasitol. Int. 2010, 59, 154-158, https://doi.org/10.1016/j.parint.2009.12.009.

61. Felipe, D.F.; Filho, B.P.D.; Nakamura, C.V.; Cortez, D.A.G. Evaluation of the antimicrobial activity of Piper regnellii (Miq.) C.DC. var. pallescens (C.DC.) Yunck. Lat. Am. J. Pharm. 2008, 27, 618-620.

62. Duarte, M.C.; Figueira, G.M.; Sartoratto, A.; Rehder, V.L.; Delarmelina, C. Anti-candida activity of Brazilian medicinal plants. J. Ethnopharmacol. 2005, 97, 305-311, https://doi.org/10.1016/j.jep.2004.11.016.

63. Johann, S.; Silva, D.L.; Martins, C.V.B.; Zani, C.L.; Pizzolatti, M.G.; Resende, M.A. Inhibitory effect of extracts from Brazilian medicinal plants on the adhesion of Candida albicans to buccal epithelial cells. World J. Microbiol. Biotech. 2008, 24, 2459-2464, https://doi.org/10.1007/s11274-008-9768-5. 
64. Holetz, F.B.; Pessini, G.L.; Sanches, N.R.; Cortez, D.A.G.; Nakamura, C.V.; Dias-Filho, B.P. Screening of some plants used in the Brazilian folk medicine for the treatment of infectious diseases. Mem. Inst. Oswaldo Cruz 2002, 97, 1027-1031, https://doi.org/10.1590/s0074-02762002000700017.

65. Johann, S.; Cisalpino, P.S.; Watanabe, G.A.; Cota, B.B.; De Siqueira, E.P.; Pizzolatti, M.G.; Zani, C.L.; De Resende, M.A. Antifungal activity of extracts of some plants used in Brazilian traditional medicine against the pathogenic fungus Paracoccidioides brasiliensis. Pharm. Biol. 2010, 48, 388-396. https://doi.org/10.3109/13880200903150385.

66. Koroishi, A.M.; Sehn, E.; Baesso, M.L.; Ueda-Nakamura, T.; Nakamura, C.V.; Cortez, D.A.G.; Filho, B.P.D. Antifungal activity and nail permeation of nail lacquer containing Piper regnellii (Miq.) var. pallescens (C.DC.) Yunck (Piperaceae) leave extracts and derivatives. Molecules 2010, 15, 3920-3931, https://doi.org/10.3390/molecules15063920.

67. Schmidt, C.; Fronza, M.; Goettert, M.; Geller, F.; Luik, S.; Flores, E.M.M.; Bittencourt, C.F.; Zanetti, G.D.; Heinzmann, B.M.; Laufer, S.; Merfort, I. Biological studies on Brazilian plants used in wound healing. $J$. Ethnopharmacol. 2009, 122, 523-532, https://doi.org/10.1016/j.jep.2009.01.022.

68. Luize, P.S.; Tiuman, T.S.; Morello, L.G.; Maza, P.K.; Ueda-Nakamura, T.; Dias Filho, B.P.; Cortez, D.A.G.; De Mello, J.C.P.; Nakamura, C.V. Effects of medicinal plant extracts on growth of Leishmania (L.) amazonensis and Trypanosoma cruzi. Braz. J. Pharm. Sci. 2005, 41, 85-94, https://doi.org/10.1590/S151693322005000100010 . 